\title{
Badania zmian wspólczynnika filtracji w zależności od wskaźnika porowatości w gruntach słabonośnych
}

\author{
Marzena Jaromińska \\ Zakład Geotechniki I Budownictwa Drogowego, Instytut Budownictwa, \\ Wydziat Geodezji, Inżynierii Przestrzennej I Budownictwa, Uniwersytet Warmińsko-Mazurski, \\ e-mail:marzna.jarominska@gmail.com
}

Streszczenie: W artykule przedstawiono wyniki analizy prostej regresji liniowej współczynnika filtracji $k$ i wskaźnika porowatości $e$ gruntów organicznych. Analizie poddano 8 próbek gytii mineralno-organicznej pochodzących z okolic Olsztyna. Opisano metodykę badań i przeanalizowano zależność $e-\log k$ przy pięciu stopniach obciążenia. W wyniku przeprowadzonej analizy stwierdzono, że modele regresji liniowej budowane na bazie tylko statystycznie istotnych wyników badań pozwalają wyjaśnić ponad $75 \%$ zmienności log $k$. Wysokie wartości statystyki $\mathrm{F}$ potwierdzają istotność modelu liniowego. Wyniki badań wskazują, że procedura badania edometrycznego nie uwzględnia wielu czynników, które mają wpływ na właściwości filtracyjne gruntu. Identyfikacja korelacji pomiędzy współczynnikiem filtracji i wskaźnikiem porowatości ma kluczowe znaczenie w rozpoznaniu mechanizmu powiązań między tymi cechami.

Słowa kluczowe: współczynnik filtracji, grunt słabonośny, regresja liniowa.

\section{Wprowadzenie}

Coraz powszechniejsze lokalizowanie obiektów inżynierskich na gruntach organicznych powoduje wzrost zainteresowania zarówno cechami fizycznymi, jak i mechanicznymi tych gruntów. Niezbędna jest wiedza o parametrach związanych z odkształceniem oraz zmianą przepuszczalności gruntu pod zmieniającym się obciążeniem. Na tej podstawie możemy prognozować odkształcenia konsolidacyjne podłoża [1]. Znajomość tendencji zmian przepuszczalności gruntu w czasie, przy wzrastającej składowej pionowej naprężenia, umożliwi przewidywanie, na podstawie parametrów początkowych, jakie właściwości filtracyjne będzie miał grunt po ustabilizowaniu osiadań [2].

Grunty organiczne mają bardzo niekorzystne parametry geotechniczne. Są gruntami słabymi. Cechuje je duża zmienność właściwości fizyko-mechanicznych [1, 3, 4]. Są bardzo wrażliwe na wszystkie kolejne etapy badania, począwszy od wyboru sposobu pobrania próbki aż do wyboru wykorzystanej aparatury i metody badań. Dlatego dosyć ważne wydaje się standaryzowanie wyników badań poprzez poszukiwanie istotnych związków cech gruntów. Trudno jest jednoznacznie stwierdzić, w jaki sposób poszczególne cechy gruntu kształtują jego przepuszczalność. Wszystkie właściwości w jakiś sposób są od siebie uzależnione a związki między nimi są różne i zmieniają się w czasie.

Dotychczasowe badania zależności $e-\log k$ dla gruntów drobnoziarnistych najczęściej wykazują, że istnieje liniowa zależność pomiędzy tymi cechami [5, 6]. Wyniki doświadczalne badań gytii mineralno-organicznej potwierdzają tezę o liniowej zależności pomiędzy współczynnikiem filtracji i wskaźnikiem porowatości, jednak dopiero po wykluczeniu „błędów” statystycznych. Obecność takich „błędów” dowodzi, że na przepuszczalność gruntu mają wpływ jeszcze inne czynniki $[7,8,9,10]$. 
W niniejszym artykule przedstawiono wyniki badań korelacji pomiędzy współczynnikiem filtracji $k$ oraz wskaźnikiem porowatości $e$, zmieniających się pod obciążeniem. Określono siłę tego związku oraz mechanizm powiązań między zmiennymi w postaci równań regresji.

\section{Charakterystyka metody laboratoryjnych badań współczynnika filtracji $k$}

Do analizy przebiegu zmian przepuszczalności gruntu wraz ze zmianą wskaźnika porowatości wykorzystano wyniki badań edometrycznych przy zmiennym spadku hydraulicznym. Były to badania konsolidacji jednoosiowej prowadzone metodą IL (incremental loading). Badania wykonano w klasycznych edometrach, typu ITB-ZW, przystosowanych do wyznaczania współczynnika filtracji. Wszystkie próbki poddawane były obciążeniom 0-200 kPa, w pięciu kolejnych stopniach. Współczynniki filtracji określane były przed pierwszym etapem konsolidacji oraz po zakończeniu konsolidacji przy każdym następnym stopniu obciążenia. Badania $k$ prowadzono przy zablokowanym odkształceniu próbek, po upływie pięciu dób od momentu zakończenia konsolidacji. Zwiększenie obciążenia następowało po umownej stabilizacji osiadań, tj. gdy zmiany wysokości próbki nie były większe niż 0,003 mm [11]. Czas konsolidowania próbek był bardzo długi i zmieniał się wraz z postępem konsolidacji i zmianą zdolności filtracyjnych gruntu. Przy pierwszym obciążeniu, $12,5 \mathrm{kPa}$, całkowita zmiana wysokości próbki nastąpiła dopiero po ok. 20 miesiącach badania. Przy obciążeniu $25 \mathrm{kPa}$ czas ten skrócił się o połowę, do ok. 9 miesięcy. Kolejne stadia badania trwały 4 i 3 miesiące. Kierunek przepływu wody był wymuszony od dołu do góry. Spadki hydrauliczne zmieniały się w zakresie od 30 do 120. Zastosowanie tak wysokich spadków wynikało z potrzeby zminimalizowania błędów pomiarowych, wynikających z mechanicznego przeciekania, głównie wzdłuż ścian pierścienia edometru, oraz z niewielkiej rozszerzalności bocznej [12].

Wykorzystane w analizie badania jednoosiowego ściskania pozwalają na dokładną obserwację zmian objętości gruntu pod wpływem obciążenia, umożliwiają określenie zmian porowatości gruntu i ilości przepływającej przez grunt wody przy wzrastających składowych pionowych naprężenia efektywnego.

Wskaźniki porowatości e wyznaczono, posługując się formułą opisującą zależność między $e_{i}$ i $h_{i}[13]$ :

$$
e_{i}=e_{0}-\frac{\Delta h_{i}}{h_{0}}\left(1+e_{0}\right)
$$

Dla każdej z 8 prób, przy pięciu kolejnych stopniach obciążenia, określono zależność współczynnika filtracji $k$ od wskaźnika porowatości $e$, zbadano siłę korelacji między tymi zmiennymi oraz przeprowadzono badanie regresji liniowej.

\section{Wyniki przeprowadzonych badań i ich analiza}

Badanie zmienności współczynnika filtracji $k$ w zależności od wskaźnika porowatości $e$ oraz rodzaju tej zależności przeprowadzono dla wybranych prób gruntu organicznego z rejonu Olsztyna (Guzowy Młyn, Unieszewo, Różnowo). Do analizy wybrano 8 prób gytii mineralno-organicznej o zbliżonych cechach fizycznych (Tab. 1). Wszystkie właściwości gruntu były określane na podstawie normy PN-88/B-04481 i ogólnie znanych zależności [13]. Wartość średnia gęstości objętościowej $\rho$ równa jest $1,14 \mathrm{~g} / \mathrm{cm}^{3}$, gęstości właściwej 
szkieletu gruntowego $\rho_{s}=2,21 \mathrm{~g} / \mathrm{cm}^{3}$ a gęstości objętościowej szkieletu gruntowego $\rho_{d}=0,26 \mathrm{~g} / \mathrm{cm}^{3}$. Minimalne wartości odchylenia standardowego potwierdzają niewielki rozrzut tych cech wokół ich średniej wartości. Podobnie niewiele różnią się w poszczególnych próbach porowatość $n\left(n_{s r}=0,88\right)$ oraz stopień wilgotności $S_{r}\left(S_{r s ́}^{\prime}=0,982\right)$. Wartość środkowa (mediana) pokrywa się tu niemal z wartością średnią. Główną cechą, która determinowała wybór prób do badań była zawartość części organicznych. Dobrano próby tak, aby wyeliminować wpływ struktury gruntu na przebieg badania przepuszczalności. Średnia wartość $C_{O M}$ równa jest 20,82\%. Rozrzut wokół średniej wynosi 7,09. Jedyną cechą, która będzie brana pod uwagę, jako czynnik mający wpływ na zachowanie się gruntu pod obciążeniem a tym samym zmiany przepuszczalności gruntu wraz ze wzrostem obciążenia, będzie wskaźnik porowatości e. Odchylenie standardowe $e$ stanowi 29,21\% wartości średniej $\left(e_{s r}=8,13\right)$.

Wyniki badań współczynnika filtracji przedstawiono w tabeli 2. Podano zakres zmian wartości pomierzonych współczynników filtracji, pierwszy i ostatni pomiar przy danym obciążeniu oraz wartość średnią wszystkich pomiarów. Zbliżone właściwości fizyczne analizowanych gytii mineralno-organicznych skutkują podobnym zachowaniem się próby pod obciążeniem i podobną zmiennością współczynnika filtracji.

Tabela 1. Właściwości fizyczne analizowanych gytii

\begin{tabular}{|c|c|c|c|c|c|c|c|c|}
\hline & $\begin{array}{l}\rho \\
{\left[\mathrm{g} / \mathrm{cm}^{3}\right]}\end{array}$ & $\begin{array}{l}\rho_{s} \\
{\left[\mathrm{~g} / \mathrm{cm}^{3}\right]}\end{array}$ & $\begin{array}{l}\rho_{d} \\
{\left[\mathrm{~g} / \mathrm{cm}^{3}\right]}\end{array}$ & $\begin{array}{l}w \\
{[\%]}\end{array}$ & $\begin{array}{l}n \\
{[-]}\end{array}$ & $\begin{array}{l}e \\
{[-]}\end{array}$ & $\begin{array}{l}C_{o m} \\
{[\%]}\end{array}$ & $\begin{array}{l}S_{r} \\
{[-]}\end{array}$ \\
\hline Liczba pomiarów & 8 & 8 & 8 & 8 & 8 & 8 & 8 & 8 \\
\hline Wartość minimalna & 1,07 & 1,99 & 0,16 & 214,4 & 0,84 & 5,10 & 12,00 & 0,943 \\
\hline Wartość maksymalna & 1,24 & 2,39 & 0,39 & 575,6 & 0,92 & 11,87 & 30,41 & 0,999 \\
\hline Średnia arytmetyczna & 1,14 & 2,21 & 0,26 & 368,78 & 0,88 & 8,13 & 20,82 & 0,982 \\
\hline Odchylenie standardowe & 0,06 & 0,17 & 0,08 & 132,67 & 0,03 & 2,37 & 7,09 & 0,02 \\
\hline Współczynnik zmienności & 5,54 & 7,71 & 32,70 & 35,98 & 3,19 & 29,21 & 34,09 & 2,11 \\
\hline Mediana & 1,13 & 2,21 & 0,25 & 344,60 & 0,88 & 7,70 & 20,48 & 0,990 \\
\hline
\end{tabular}

W niemal wszystkich próbkach przepuszczalność zmienia się od nE-09 [m/s] dla obciążenia $12,5 \mathrm{kPa}$ do $\mathrm{nE}-11 \div 12[\mathrm{~m} / \mathrm{s}]$, max. nE-13 [m/s] dla $200 \mathrm{kPa}$. Wyjątkowo słabą przepuszczalnością charakteryzuje się próbka nr 7. Jest to gytia mineralno-organiczna, która wyróżnia się na tle analizowanych prób, najwyższym wskaźnikiem porowatości początkowej $(e=11,868)$. Z kolei próba nr 5 wykazała szczególnie dużą przepuszczalność, od nE-07 $[\mathrm{m} / \mathrm{s}]$ dla $12,5 \mathrm{kPa}$ do $\mathrm{nE}-08[\mathrm{~m} / \mathrm{s}]$ dla $200 \mathrm{kPa}$. Żadna $\mathrm{z}$ określonych cech gruntu nie wyróżnia tej próby na tle pozostałych. Wyraźnie inny przebieg zmian współczynnika filtracji w zależności od naprężenia $\sigma^{\prime}$, w przypadku tej próby widoczny jest na rysunku 1 .

Dla każdej próby określono również zależność współczynnika filtracji $k$ od wskaźnika porowatości $e$ oraz obliczono siłę zależności między tymi zmiennymi. Badania wykazały, że wraz z redukcją wskaźnika porowatości e przepuszczalność znacznie się zmienia. Tendencja tych zmian wprawdzie wykazuje dosyć wyraźną prawidłowość, ale nie zawsze może być opisana za pomocą funkcji liniowej. Na rysunku 2 pokazano przykładowe rozrzuty log $k$ vs. $e$ dla dwóch wybranych prób.

W celu określenia siły oraz rodzaju powiązań miedzy zmiennymi obliczono współczynniki korelacji liniowej Pearsona wraz ze współczynnikami determinacji oraz obliczono równania regresji liniowej. 
Obliczenia statystyczne przeprowadzono przy 95\% poziomie ufności $(p \leq 0,05)$. Według tak przyjętego poziomu ufności wartości zakreślone w tabeli 3 są błędami, nie odzwierciedlają rzeczywistej zależności. Statystycznie zależności te nie są istotne.

Tabela 2. Zbiorcze zestawienie wyników badań współczynnika filtracji $\mathrm{k}[\mathrm{m} / \mathrm{s}]$

\begin{tabular}{|c|c|c|c|c|c|c|}
\hline \multirow{2}{*}{$\begin{array}{l}\mathrm{Nr} \\
\text { próby }\end{array}$} & \multirow{2}{*}{$\begin{array}{l}\text { Zakres wartości } k[\mathrm{~m} / \mathrm{s}] \\
\text { Średnia wartość } k[\mathrm{~m} / \mathrm{s}]\end{array}$} & \multicolumn{5}{|c|}{ Obciążenie [kPa] } \\
\hline & & 12,5 & 25 & 50 & 100 & 200 \\
\hline \multirow[t]{2}{*}{ P1 } & zakres & $\begin{array}{l}1,3 \mathrm{E}-08 \div \\
3,4 \mathrm{E}-10\end{array}$ & $\begin{array}{l}9,5 \mathrm{E}-10 \div \\
1,9 \mathrm{E}-10\end{array}$ & $\begin{array}{l}1,9 \mathrm{E}-10 \div \\
1,4 \mathrm{E}-10\end{array}$ & $\begin{array}{l}1,4 \mathrm{E}-10 \div \\
8,5 \mathrm{E}-11\end{array}$ & $\begin{array}{l}8,5 \mathrm{E}-11 \div \\
3,4 \mathrm{E}-11\end{array}$ \\
\hline & średnia & 2,9E-09 & $2,64 \mathrm{E}-10$ & $1,41 \mathrm{E}-10$ & $1 \mathrm{E}-10$ & $4,49 \mathrm{E}-11$ \\
\hline \multirow[t]{2}{*}{$\mathrm{P} 2$} & zakres & $\begin{array}{l}3,1 \mathrm{E}-08 \div \\
4,6 \mathrm{E}-10\end{array}$ & $\begin{array}{l}1,6 \mathrm{E}-09 \div \\
3,7 \mathrm{E}-10\end{array}$ & $\begin{array}{l}3,7 \mathrm{E}-10 \div \\
1,1 \mathrm{E}-10\end{array}$ & $\begin{array}{l}1,1 \mathrm{E}-10 \div \\
5,1 \mathrm{E}-11\end{array}$ & $\begin{array}{l}5,1 \mathrm{E}-11 \div \\
1,4 \mathrm{E}-11\end{array}$ \\
\hline & średnia & 4,81E-09 & $4,35 \mathrm{E}-10$ & $1,95 \mathrm{E}-10$ & $5,6 \mathrm{E}-11$ & $2,43 \mathrm{E}-11$ \\
\hline \multirow[t]{2}{*}{ P3 } & zakres & $\begin{array}{l}6,2 \mathrm{E}-09 \div \\
3,8 \mathrm{E}-10\end{array}$ & $\begin{array}{l}1,1 \mathrm{E}-09 \div \\
1,1 \mathrm{E}-10\end{array}$ & $\begin{array}{l}1,1 \mathrm{E}-10 \div \\
2,2 \mathrm{E}-11\end{array}$ & $\begin{array}{l}2,2 \mathrm{E}-11 \div \\
1 \mathrm{E}-11\end{array}$ & $\begin{array}{l}1 \mathrm{E}-11 \div \\
7,4 \mathrm{E}-13\end{array}$ \\
\hline & średnia & $1,8 \mathrm{E}-09$ & $1,78 \mathrm{E}-10$ & $5,15 \mathrm{E}-11$ & $2,4 \mathrm{E}-11$ & $2,55 \mathrm{E}-11$ \\
\hline \multirow[t]{2}{*}{ P4 } & zakres & $\begin{array}{l}1,3 \mathrm{E}-08 \div \\
1,9 \mathrm{E}-09\end{array}$ & $\begin{array}{l}9 \mathrm{E}-09 \div \\
5,9 \mathrm{E}-10\end{array}$ & $\begin{array}{l}5,9 \mathrm{E}-10 \div \\
3,2 \mathrm{E}-10\end{array}$ & $\begin{array}{l}2,7 \mathrm{E}-10 \div \\
1 \mathrm{E}-10\end{array}$ & $\begin{array}{l}1,5 \mathrm{E}-10 \div \\
1,2 \mathrm{E}-10\end{array}$ \\
\hline & średnia & 2,4E-08 & 1,41E-09 & $3,72 \mathrm{E}-10$ & $1,06 \mathrm{E}-10$ & $1,27 \mathrm{E}-10$ \\
\hline \multirow[t]{2}{*}{ P5 } & zakres & $\begin{array}{l}1,37 \mathrm{E}-07 \div \\
1,15 \mathrm{E}-07\end{array}$ & $\begin{array}{l}1,4 \mathrm{E}-07 \div \\
5,4 \mathrm{E}-08\end{array}$ & $\begin{array}{l}5,3 \mathrm{E}-0 \div \\
4,2 \mathrm{E}-08\end{array}$ & $\begin{array}{l}4,2 \mathrm{E}-08 \div \\
3,1 \mathrm{E}-08\end{array}$ & $\begin{array}{l}3,1 \mathrm{E}-08 \div \\
1,8 \mathrm{E}-08\end{array}$ \\
\hline & średnia & $1,16 \mathrm{E}-07$ & $8,14 \mathrm{E}-08$ & 4,95E-08 & 3E-08 & $2,23 \mathrm{E}-08$ \\
\hline \multirow[t]{2}{*}{ P6 } & zakres & $\begin{array}{l}2,4 \mathrm{E}-08 \div \\
5,9 \mathrm{E}-10\end{array}$ & $\begin{array}{l}3,1 \mathrm{E}-10 \div \\
6,1 \mathrm{E}-11\end{array}$ & $\begin{array}{l}6,1 \mathrm{E}-11 \div \\
7,9 \mathrm{E}-12\end{array}$ & $\begin{array}{l}7,9 \mathrm{E}-12 \div \\
1,3 \mathrm{E}-12\end{array}$ & $\begin{array}{l}1,9 \mathrm{E}-12 \div \\
2,6 \mathrm{E}-13\end{array}$ \\
\hline & średnia & 2,43E-09 & $1,32 \mathrm{E}-10$ & $2,3 \mathrm{E}-11$ & $2,2 \mathrm{E}-11$ & $1,93 \mathrm{E}-11$ \\
\hline \multirow[t]{2}{*}{ P7 } & zakres & $\begin{array}{l}6,9 \mathrm{E}-08 \div \\
5,8 \mathrm{E}-11\end{array}$ & $\begin{array}{l}1,6 \mathrm{E}-10 \div \\
1,3 \mathrm{E}-11\end{array}$ & $\begin{array}{l}1,3 \mathrm{E}-11 \div \\
6,2 \mathrm{E}-12\end{array}$ & $\begin{array}{l}6,2 \mathrm{E}-12 \div \\
1 \mathrm{E}-13\end{array}$ & $\begin{array}{l}1 \mathrm{E}-13 \div \\
7,8 \mathrm{E}-14\end{array}$ \\
\hline & średnia & 2,57E-09 & $2,41 \mathrm{E}-11$ & $5,04 \mathrm{E}-12$ & $5,96 \mathrm{E}-12$ & $1,24 \mathrm{E}-13$ \\
\hline \multirow[t]{2}{*}{ P8 } & zakres & $\begin{array}{l}7,7 \mathrm{E}-08 \div \\
5,9 \mathrm{E}-11\end{array}$ & $\begin{array}{l}4,1 \mathrm{E}-10 \div \\
1,7 \mathrm{E}-11\end{array}$ & $\begin{array}{l}1,7 \mathrm{E}-11 \div \\
1,3 \mathrm{E}-11\end{array}$ & $\begin{array}{l}1,3 \mathrm{E}-11 \div \\
6,2 \mathrm{E}-13\end{array}$ & $\begin{array}{l}6,2 \mathrm{E}-13 \div \\
9,8 \mathrm{E}-13\end{array}$ \\
\hline & średnia & 3,81E-09 & $6,62 \mathrm{E}-11$ & $1 \mathrm{E}-11$ & $3,01 \mathrm{E}-11$ & $6,29 \mathrm{E}-12$ \\
\hline
\end{tabular}

Zmiana współczynnika filtracji wraz z obciążeniem, od 12,5 do $200 \mathrm{kPa}$

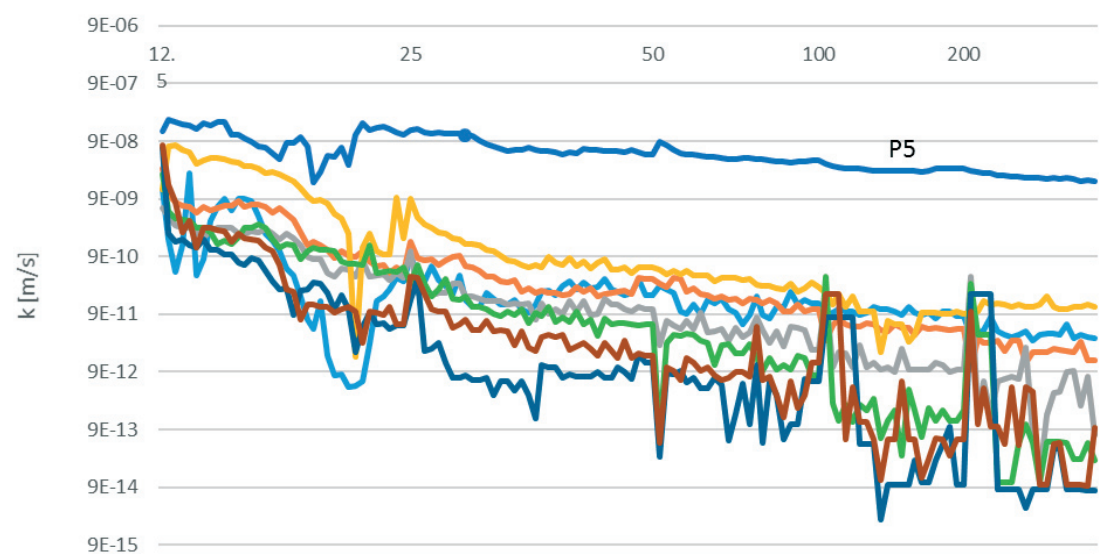

$9 \mathrm{E}-15$

Rys. 1. Zmiana współczynnika filtracji w zależności od naprężenia $\sigma^{\prime}$ 
P1

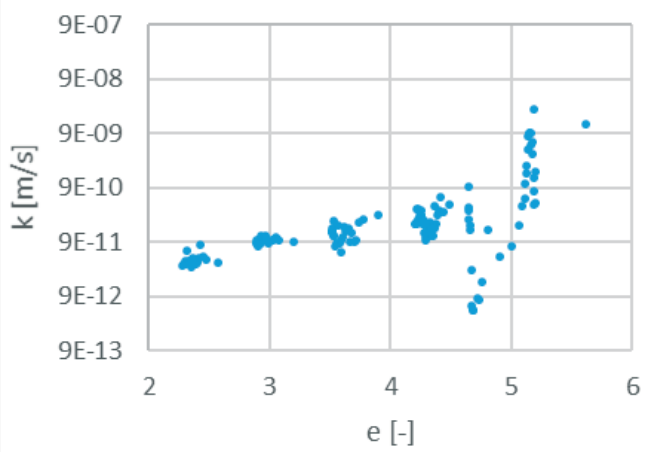

P6

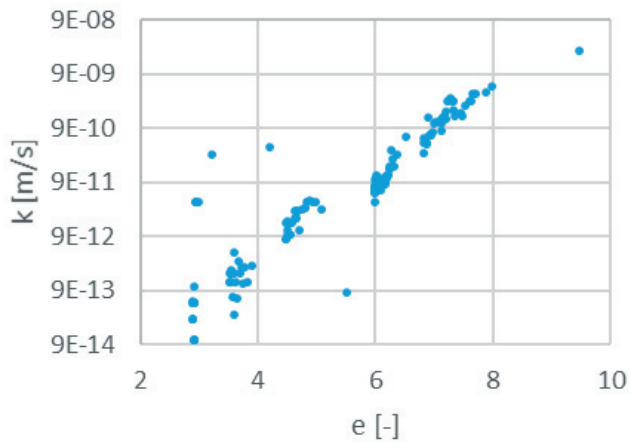

Rys. 2. Zmiana współczynnika filtracji wraz ze zmianą wskaźnika porowatości

Tabela 3. Współczynniki korelacji i determinacji $e-\log k$

\begin{tabular}{lllllll}
\hline \multirow{2}{*}{$\begin{array}{l}\text { Nr } \\
\text { próby }\end{array}$} & współczynniki & \multicolumn{2}{l}{ Obciążenie $[\mathrm{kPa}]$} & 50 & 100 & 200 \\
\cline { 2 - 6 } P1 & $\mathrm{r}(\mathrm{X}, \mathrm{Y})$ & 0,78 & 0,45 & 0,41 & 0,52 & 0,60 \\
\hline & $\mathrm{r}^{2}$ & 0,61 & 0,20 & 0,17 & 0,27 & 0,36 \\
\hline P2 & $\mathrm{r}(\mathrm{X}, \mathrm{Y})$ & 0,87 & 0,87 & 0,75 & 0,46 & 0,47 \\
\hline & $\mathrm{r}^{2}$ & 0,76 & 0,76 & 0,57 & 0,21 & 0,22 \\
\hline P3 & $\mathrm{r}(\mathrm{X}, \mathrm{Y})$ & 0,92 & 0,83 & 0,40 & 0,61 & 0,43 \\
\hline & $\mathrm{r}^{2}$ & 0,84 & 0,69 & 0,16 & 0,37 & 0,18 \\
\hline P4 & $\mathrm{r}(\mathrm{X}, \mathrm{Y})$ & 0,72 & 0,45 & 0,83 & 0,53 & 0,45 \\
\hline & $\mathrm{r}^{2}$ & 0,52 & 0,21 & 0,69 & 0,29 & 0,21 \\
\hline P5 & $\mathrm{r}(\mathrm{X}, \mathrm{Y})$ & 0,13 & 0,86 & 0,73 & 0,85 & 0,94 \\
\hline & $\mathrm{r}^{2}$ & 0,02 & 0,74 & 0,54 & 0,73 & 0,88 \\
\hline P6 & $\mathrm{r}(\mathrm{X}, \mathrm{Y})$ & 0,90 & 0,85 & 0,09 & 0,65 & 0,49 \\
\hline & $\mathrm{r}^{2}$ & 0,81 & 0,72 & 0,007 & 0,42 & 0,24 \\
\hline P7 & $\mathrm{r}(\mathrm{X}, \mathrm{Y})$ & 0,82 & 0,68 & 0,21 & 0,75 & 0,42 \\
\hline P8 & $\mathrm{r}^{2}$ & 0,67 & 0,46 & 0,04 & 0,57 & 0,18 \\
\hline & $\mathrm{r}(\mathrm{X}, \mathrm{Y})$ & 0,78 & 0,94 & $-0,008$ & 0,68 & 0,40 \\
\hline & $\mathrm{r}^{2}$ & 0,61 & 0,88 & 0,00006 & 0,46 & 0,16 \\
\hline
\end{tabular}

Aby opisać siłę związku pomiędzy współczynnikiem filtracji $k$ a wskaźnikiem porowatości e przyjęto klasyfikację J. P. Guilford'a [14]:

$\begin{array}{ll}\mathrm{r}=0 & \text { brak korelacji } \\ 0,0<\mathrm{r} \leq 0,1 & \text { korelacja niska } \\ 0,1<\mathrm{r} \leq 0,3 & \text { korelacja słaba } \\ 0,3<\mathrm{r} \leq 0,5 & \text { korelacja przeciętna } \\ 0,5<\mathrm{r} \leq 0,7 & \text { korelacja wysoka } \\ 0,7<\mathrm{r} \leq 0,9 & \text { korelacja bardzo wysoka } \\ 0,9<\mathrm{r}<1 & \text { korelacja prawie pełna } \\ \mathrm{r}=1 & \text { korelacja pełna }\end{array}$

Najsilniejsze korelacje stwierdzono dla dwóch pierwszych stopni obciążenia 12,5 kPa oraz $25 \mathrm{kPa}$. Występują tu korelacje wysokie, bardzo wysokie a nawet prawie pełne, dla których współczynniki determinacji $\mathrm{r}^{2}$ przekraczają 50\%. W przypadku trzech próbek (P2, P4 i P5) tak silne związki zaobserwowano również przy obciążeniu $50 \mathrm{kPa}$. Jest to jednocześnie ten stopień obciążenia, w przypadku którego uzyskano najwięcej wyników nieistotnych statystycznie. Dosyć silne korelacje pojawiają się znów przy obciążeniu $100 \mathrm{kPa}$, ale 
tylko w przypadku dwóch próbek (P5 i P7) współczynnik determinacji przekracza 50\%. Przy obciążeniu $200 \mathrm{kPa}$ korelację prawie pełną wykazała próbka $\mathrm{nr} 5(\mathrm{r}=0,94)$, przy $r^{2}=0,88$. W próbce P1 stwierdzono wprawdzie wysoką korelację $(r=0,6)$ ale $r^{2}$ jest mniejszy niż 50\% $\left(\mathrm{r}^{2}=0,36\right)$.

W celu określenia rodzaju powiązań między zmiennymi $e$ i log $k$ oszacowano funkcje regresji liniowej prostej. $\mathrm{Z}$ analizy wykluczono te wyniki badań, które uznano za statystycznie nieistotne. Do deterministycznego równania log $k=\mathrm{f}(e)$ wprowadzono zmienną losową $u_{i}$ i założono, że rzeczywista zależność współczynnika filtracji $k$ od wskaźnika porowatości e ma charakter stochastyczny. W ogólnej postaci model regresji liniowej prostej możemy zapisać jako:

$$
\log k=\mathrm{f}\left(e, u_{\mathrm{i}}\right)
$$

W analizie regresji przyjęto kilka podstawowych, standardowych założeń [15], tj. relacja f jest stabilna, zmienna losowa $u_{i}$ ma rozkład normalny $\mathrm{N}\left(0, \sigma^{2}\right)$, model jest liniowy względem parametrów

$$
\log k=\beta_{1} \cdot e-\beta_{0} \mp u_{i}
$$

gdzie $\beta_{0}$ i $\beta_{1}$ to parametry strukturalne modelu, które szacuje się za pomocą metody najmniejszych kwadratów. Współczynnik regresji $\beta_{1}$ informuje nas jakiej przeciętnej zmiany wartości zmiennej zależnej możemy się spodziewać, gdy wartość zmiennej niezależnej zmieni się o jedną jednostkę.

Najważniejszym założeniem jest normalność rozkładu składnika losowego $\left(u_{i}\right)$ ponieważ dopiero spełnienie tego założenia pozwala na przeprowadzenie wnioskowania statystycznego. Wyniki testu Shapiro-Wilka oraz wykresy normalności reszt nie dały podstaw do kwestionowania normalności rozkładu składnika losowego, a tym samym potwierdziły poprawność wyników analizy regresji.

Tabela 4 przedstawia równania regresji liniowej z podziałem na grupy (zmienną grupującą jest obciążenie) oraz bez podziału na grupy - dla całego cyklu badania. Podano tu również wartość statystyki $\mathrm{F}$, wartość współczynnika korelacji Pearsona $\mathrm{r}(\mathrm{X}, \mathrm{Y})$ oraz w jakim stopniu model wyjaśnia zmienność współczynnika filtracji, czyli wartość współczynnika determinacji $\mathrm{r}^{2}$.

Analiza równań regresji liniowej, bez podziału na grupy, wykazuje, że zmiana wartości wskaźnika porowatości e o 1 jednostkę powoduje zmianę wartości współczynnika filtracji $k$ średnio o 0,7662 . Współczynniki przesunięcia prostej regresji $\beta_{0}$ kształtują się na poziomie od 8,1 (P5) do 15,2 (P7). Wykluczając próbkę P5, która zdecydowanie różni się od pozostałych, średni współczynnik przesunięcia będzie równy 13,76. Błędy standardowe estymacji (bez P5) wahają się od 0,27 do 0,56 . To znaczy, że przewidywane wartości zmiennej log $k$ różnią się od wartości empirycznych średnio o $0,44 \%$.

Upraszczając mechanizm powiazań pomiędzy zmiennymi log $k$ oraz $e$ dla gytii mineralno- organicznej możemy zapisać równanie:

$$
\log k=0,77 \cdot e-13,76 \mp 0,44
$$

Wysokie wartości statystyk $\mathrm{F}, \mathrm{r}(\mathrm{X}, \mathrm{Y})$ oraz $\mathrm{r}^{2}$ potwierdzają statystyczną istotność modelu liniowego „oczyszczonych” prób. Zasadność aproksymacji liniowej wyjaśniają również wykresy rozrzutu log $k$ vs. $e$ (Rys. 3). W przeprowadzonej analizie pominięto przyczyny braku istotności statystycznej części wyników badań. Zagadnienia te są przedmiotem aktualnie prowadzonych analiz. 
Tabela 4. Równania zależności $e-\log k$

\begin{tabular}{|c|c|c|c|}
\hline \multirow{2}{*}{$\begin{array}{l}\mathrm{Nr} \\
\text { próbki }\end{array}$} & \multirow[t]{2}{*}{ obciążenie } & \multicolumn{2}{|l|}{ Równanie zależności $e-\log k$} \\
\hline & & Z podziałem na grupy & Bez podziału na grupy \\
\hline \multirow[t]{5}{*}{ P1 } & 12,5 & $\log k=3,4419 \cdot e-26,51 \pm 0,68$ & \multirow{5}{*}{$\begin{array}{l}\log k=0,4247 \cdot e-11,42 \pm 0,53 \\
\mathrm{~F}(73,66) \\
\mathrm{r}(\mathrm{X}, \mathrm{Y})=0,59 \\
\mathrm{r}^{2}=0,35\end{array}$} \\
\hline & 25 & $\log k=1,0525 \cdot e-14,17 \pm 0,20$ & \\
\hline & 50 & $\log k=0,45329 \cdot e-11,53 \pm 0,16$ & \\
\hline & 100 & $\log k=0,21776 \cdot e-10,65 \pm 0,05$ & \\
\hline & 200 & $\log k=0,50396 \cdot e-11,57 \pm 0,09$ & \\
\hline \multirow[t]{5}{*}{$\mathrm{P} 2$} & 12,5 & $\log k=3,4435 \cdot e-24,53 \pm 0,24$ & \multirow{5}{*}{$\begin{array}{l}\log k=0,9179 \cdot e-13,05 \pm 0,32 \\
\mathrm{~F}(673,08) \\
\mathrm{r}(\mathrm{X}, \mathrm{Y})=0,91 \\
\mathrm{r}^{2}=0,83\end{array}$} \\
\hline & 25 & $\log k=2,3062 \cdot e-19,38 \pm 0,13$ & \\
\hline & 50 & $\log k=0,78631 \cdot e-12,53 \pm 0,12$ & \\
\hline & 100 & $\log k=0,41649 \cdot e-11,52 \pm 0,09$ & \\
\hline & 200 & $\log k=0,71013 \cdot e-12,45 \pm 0,15$ & \\
\hline \multirow[t]{3}{*}{ P3 } & 12,5 & $\log k=1,7407 \cdot e-19,91 \pm 0,15$ & \multirow{3}{*}{$\begin{array}{l}\log k=0,86086 \cdot e-14,48 \pm 0,27 \\
\mathrm{~F}(718,03) \\
\mathrm{r}(\mathrm{X}, \mathrm{Y})=0,94 \\
\mathrm{r}^{2}=0,89\end{array}$} \\
\hline & 25 & $\log k=1,4341 \cdot e-17,97 \pm 0,12$ & \\
\hline & 100 & $\log k=0,9826 \cdot e-14,83 \pm 0,24$ & \\
\hline \multirow[t]{5}{*}{ P4 } & 12,5 & $\log k=2,2725 \cdot e-23,04 \pm 0,53$ & \multirow{5}{*}{$\begin{array}{l}\log k=0,68216 \cdot e-12,69 \pm 0,44 \\
\mathrm{~F}(432,19) \\
\mathrm{r}(\mathrm{X}, \mathrm{Y})=0,87 \\
\mathrm{r}^{2}=0,75\end{array}$} \\
\hline & 25 & $\log k=0,55233 \cdot e-12,17 \pm 0,27$ & \\
\hline & 50 & $\log k=0,54678 \cdot e-12,15 \pm 0,07$ & \\
\hline & 100 & $\log k=0,75294 \cdot e-13,15 \pm 0,22$ & \\
\hline & 200 & $\log k=0,14824 \cdot e-10,42 \pm 0,04$ & \\
\hline \multirow[t]{4}{*}{ P5 } & 25 & $\log k=0,71016 \cdot e-10,71 \pm 0,07$ & \multirow{4}{*}{$\begin{array}{l}\log k=0,20356 \cdot e-8,143 \pm 0,08 \\
F(828,52) \\
r(X, Y)=0,94 \\
r^{2}=0,89\end{array}$} \\
\hline & 50 & $\log k=0,27389 \cdot e-8,43 \pm 0,06$ & \\
\hline & 100 & $\log k=0,18765 \cdot e-8,11 \pm 0,03$ & \\
\hline & 200 & $\log k=0,26733 \cdot e-8,263 \pm 0,02$ & \\
\hline \multirow[t]{4}{*}{ P6 } & 12,5 & $\log k=0,67425 \cdot e-13,72 \pm 0,16$ & \multirow{4}{*}{$\begin{array}{l}\log k=0,95047 \cdot e-14,55 \pm 0,44 \\
\mathrm{~F}(1000,56) \\
\mathrm{r}(\mathrm{X}, \mathrm{Y})=0,95 \\
\mathrm{r}^{2}=0,90\end{array}$} \\
\hline & 25 & $\log k=1,2539 \cdot e-17,67 \pm 0,14$ & \\
\hline & 100 & $\log k=1,6838 \cdot e-17,91 \pm 0,48$ & \\
\hline & 200 & $\log k=2,7542 \cdot e-20,33 \pm 0,80$ & \\
\hline \multirow[t]{4}{*}{ P7 } & 12,5 & $\log k=0,61913 \cdot e-13,83 \pm 0,39$ & \multirow{4}{*}{$\begin{array}{l}\log k=0,78634 \cdot e-15,19 \pm 0,56 \\
\mathrm{~F}(604,58) \\
\mathrm{r}(\mathrm{X}, \mathrm{Y})=0,93 \\
\mathrm{r}^{2}=0,86\end{array}$} \\
\hline & 25 & $\log k=1,2210 \cdot e-17,88 \pm 0,32$ & \\
\hline & 100 & $\log k=2,6920 \cdot e-22,08 \pm 0,60$ & \\
\hline & 200 & $\log k=1,6654 \cdot e-17,36 \pm 0,79$ & \\
\hline \multirow[t]{3}{*}{ P8 } & 12,5 & $\log k=1,0858 \cdot e-17,54 \pm 0,52$ & \multirow{3}{*}{$\begin{array}{l}\log k=0,74099 \cdot e-14,94 \pm 0,56 \\
\mathrm{~F}(318,32) \\
\mathrm{r}(\mathrm{X}, \mathrm{Y})=0,88 \\
\mathrm{r}^{2}=0,78\end{array}$} \\
\hline & 25 & $\log k=1,3985 \cdot e-19,28 \pm 0,13$ & \\
\hline & 100 & $\log k=2,7012 \cdot e-22,66 \pm 0,75$ & \\
\hline
\end{tabular}
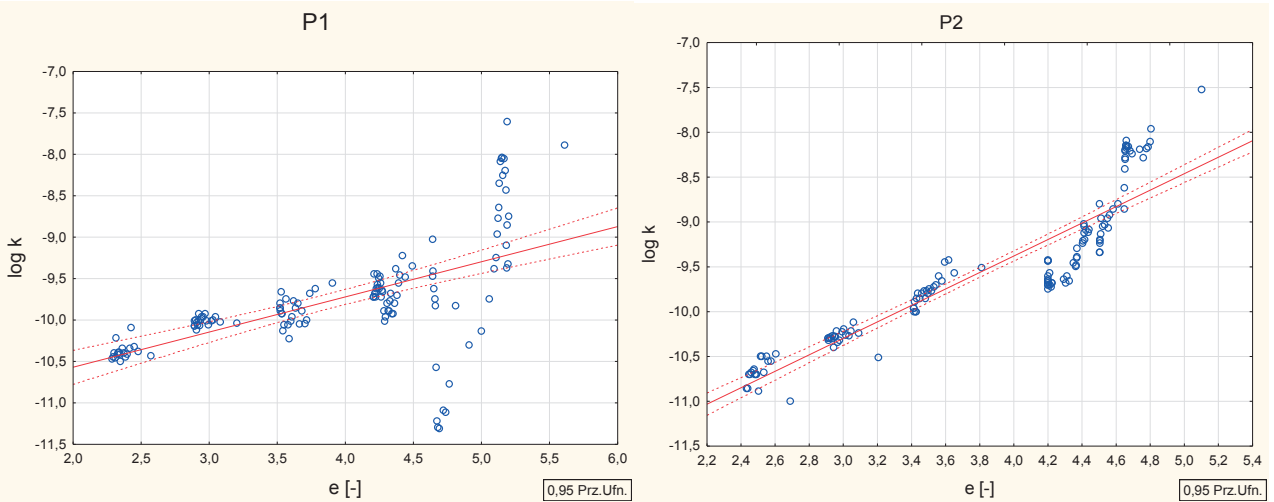

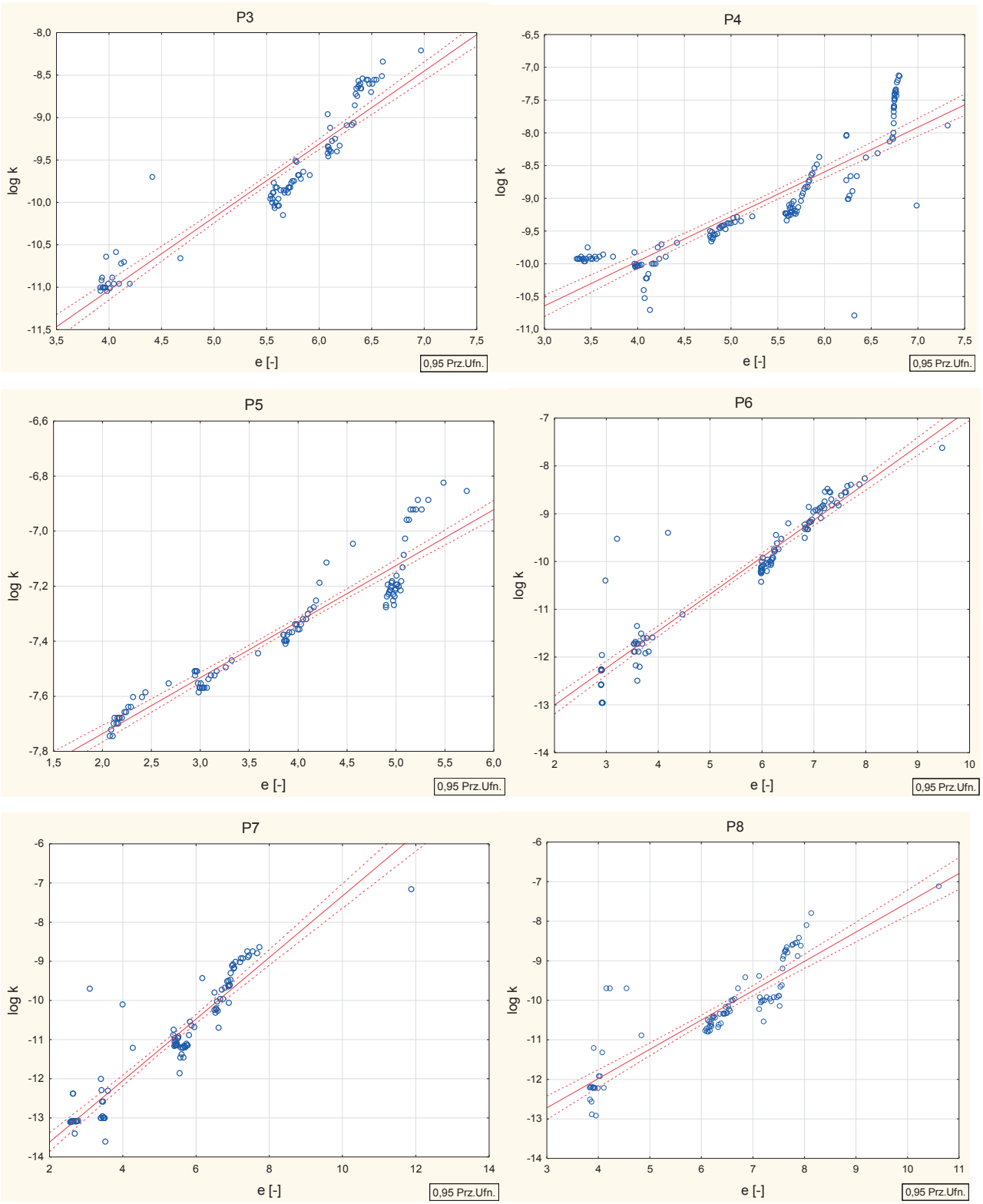

Rys. 3. Wykresy rozrzutu $e[-]$ vs. $\log k$ po oczyszczeniu danych

\section{Wnioski}

- Poszukiwanie charakteru zależności między współczynnikiem filtracji i zmniejszającym się pod obciążeniem wskaźnikiem porowatości ma bardzo duże znaczenie w ocenie odkształceń konsolidacyjnych gruntu.

- Badania statystyczne gruntów o zbliżonych cechach umożliwiają identyfikację charakteru powiązań pomiędzy e i log $k$ oraz wskazują kierunek dalszych badań. 
- Wyniki doświadczalne badań 8 prób gytii mineralno-organicznej, o zawartości części organicznych od $12 \%$ do $30 \%$, potwierdzają tezę o liniowej zależności pomiędzy współczynnikiem filtracji i wskaźnikiem porowatości, jednak dopiero po wykluczeniu „błędów” statystycznych.

- Najsilniejsze korelacje stwierdzono dla dwóch pierwszych stopni obciążenia 12,5 $\mathrm{kPa}$ oraz $25 \mathrm{kPa}$. Występują tu korelacje wysokie, bardzo wysokie a nawet prawie pełne, dla których współczynniki determinacji $\mathrm{r}^{2}$ przekraczają $50 \%$.

- Modele regresji liniowej prostej budowane na podstawie statystycznie istotnych wyników badań pozwalają wyjaśnić ponad 75\% wariancji zmiennej log $k$.

- Analiza równań regresji liniowej, bez podziału na grupy, wykazuje, że zmiana wartości wskaźnika porowatości e o 1 jednostkę powoduje zmianę wartości współczynnika filtracji $k$ średnio o 0,7662 .

- Przewidywane wartości zmiennej log $k$ różnią się od wartości empirycznych średnio o $0,44 \%$.

- Statystyczną istotność modelu liniowego potwierdzają wysokie wartości statystyki F.

- Badania mechanizmu powiązań pomiędzy współczynnikiem filtracji $k$ i wskaźnikiem porowatości e statystycznie wykluczonych wyników badań pozwolą na identyfikację innych czynników wpływających na zmieniające się pod obciążeniem właściwości filtracyjne gruntu.

\section{Literatura}

1. Hartlén J., Wolski W. (red.). Embankments on Organic Soils. Elsevier Science, 1996.

2. Jaromińska M. Wskaźnik zmian przepuszczalności gruntów słabonośnych. Budownictwo i Architektura 14(2) (2015) 43-54.

3. Wolski W. Metody badań gruntów słabych. VII Krajowa Konferencja Mechaniki Gruntów i Fundamentowania, Poznań 1984.

4. Dobak P., Kowalczyk S. Geologiczno-inżynierska analiza występowania gruntów organicznych w podłożu wybranego odcinka autostrady A2. Biuletyn Państwowego Instytutu Geologicznego 446 (2011) 257-264.

5. Samarasinghe A. M., Huang H., Yang F. ASCE \&Drnevich V.P., M. ASCE. 1982. Permeability and consolidation of normally consolidated soils. Journal of the Geotechnical Engineering Division, Proceedings of the American Society of Civil Engineers, ASCE, vol. 108, No GT6 (1982) 835-850.

6. Clarke B. G., Chen C.C. Intrinsic properties of permeability. Proceedings of the $14^{\text {th }}$ International Conference on Soil Mechanics and Foundation Engineering, 6-12 September, Hamburg, Germany, 1 (1987) 259-262.

7. Ahuja L.R., Cassel D.K., Bruce R.R., Barnes B.B. Evaluation of spatial distribution of hydraulic conductivity using effective porosity data. Soil Sci. 148 (1989) 404-411.

8. Ahuja L.R., Wendroth O., Nielsen D.R. Relationship between drainage of surface soil and average profile saturated conductivity. Soil Sci. Soc. Am. J. 57 (1993) 19-25.

9. Franzmeier D.P., Estimation of hydraulic conductivity from effective porosity data for some Indiana soils. Soil Sci. Soc. Am. J. 55 (1991) 1801-1803.

10. Timlin D.J., Ahuja L.R., Pachepsky Ya., Williams R.D. Gimenez D., Rawls W. Use of BrooksCorey parameters to improve estimates of saturated conductivity from effective porosity. Soil Sci. Soc. Am. J. 63 (1999) 1086-1092.

11. Piaskowski A. Instrukcja ITB nr 289, 1989.

12. Dobak P. Określenie przepuszczalności gruntów spoistych w badaniach konsolidacji z ciaglym przyrostem obciązenia. Przegląd Geologiczny 55(2) (2007) 126-132.

13. Wiłun Z. Zarys geotechniki. Wyd. Komunikacji i Łączności, Warszawa, 1987. 
14. Guilford J.P. Podstawowe metody statystyczne w psychologii i pedagogice. PWN, Warszawa, 1964.

15. Welfe A. Ekonometria. Metody i ich zastosowanie. PWE, 2009.

\title{
Investigation the changes of permeability coefficient depend- ing on the void ratio in soft soil
}

\section{Marzena Jaromińska}

Chair of Geotechnics and Road Engineering, Faculty of Geodesy, Geospatial and Civil Engineering, University of Warmia and Mazury, ul. Heweliusza 4, 10-724 Olsztyn, Poland, e-mail:marzna.jarominska@gmail.com

\begin{abstract}
This paper presents the results of analyses of the simple linear of regression permeability coefficient and void ratio in organic soils. Eight samples of gyttjas coming from the area of Olsztyn were analyzed. The research methodology was described and the $e$ $-\log k$ relationship was tested under five loads variants. The linear regression models built on the basis of statistically significant results explained more than $75 \%$ variability $\log k$, as it was found as a result of the performed analysis. The high values of $F$ statistics affirm the significance of the linear model. The results indicate that oedometer test procedure does not include many factors contributing to soil permeability properties. The precise identification of the dependence of the filtration coefficient $k$ on the void ratio $e$ is critical in recognizing the mechanism of relationship between these characteristics.
\end{abstract}

Keywords: permeability coefficient, organic soil, linear regression. 